\title{
Rendörség a koronavírus ellen
}

\section{SKORKA Tamás ${ }^{1}$}

\begin{abstract}
A koronavírus okozta megbetegedések miatt kialakult világjárvány elérte Magyarországot is, és a helyzet kezelése érdekében bevezetett intézkedések az egész országra nézve komoly következményekkel jártak. Tanulmányom a rendôrségre háruló feladatokat vizsgálja, ezen belül is föként az államhatáron bevezetett intézkedéseket ismerteti. A tanulmányhoz szorosan kapcsolódik másik írásom, amely a rendőrségen belül az igazgatásrendészeti szolgálati ág feladatait részletezi, a veszélyhelyzet kapcsán bevezetett új szabálysértési tényállások ismertetése révén.
\end{abstract}

Kulcsszavak: koronavírus, veszélyhelyzet, határellenőrzés, tranzitálás, méltányos beléptetés, karantén

\section{Mivel állunk szemben?}

A Konzuli Szolgálat a honlapján az alábbi tájékoztatást tette közzé: „Az Egészségügyi Világszervezet (WHO) kínai irodájához 2019. december 31-én érkezett jelzések alapján a közép-kínai Hubei tartományának székhelyén, Wuhanban ismeretlen eredetű tüdőgyulladásos megbetegedéseket regisztráltak, amelyek okozójaként a kínai hatóságok 2020. január 7-én új típusú koronavírust (SARS-CoV-2) azonosítottak."

Több típusú koronavírus van, amelyek hatásai az emberi szervezetre eltérőek. A fertőzés okozta megbetegedések is eltérő súlyúak, azonban „a Közel-Keleti légúti koronavírus (MERS-CoV) és a súlyos akut légúti tünetegyüttest okozó koronavírus (SARS-CoV) súlyos, akár életveszélyes légúti megbetegedésekhez is vezethet. Az új koronavírus elnevezése "súlyos akut légúti tünetegyüttest okozó koronavírus 2« (SARS-CoV-2), az általa okozott megbetegedés pedig a »koronavírus-betegség 2019« (Coronavirus Disease 2019), melynek rövidített elnevezése a Covid-19."2

A fertőzés emberről emberre is terjed cseppfertőzés és a fertőzött váladékokkal kapcsolatos érintkezés révén. A megbetegedés jellemzően lázzal (a betegek 88\%-ánál), száraz köhögéssel (68\%), fáradékonysággal (38\%), kisebb arányban nehéz légzéssel, torok-, illetve fejfájással, ízületi fájdalmakkal, hidegrázással, hányással, hasmenéssel járhat. A betegség leggyakrabban enyhe vagy közepesen súlyos (körülbelül 80\%-ban),

\footnotetext{
Dr. SKORKA Tamás r. alezredes, mesteroktató, Nemzeti Közszolgálati Egyetem, Rendészettudományi Kar, Közjogi és Rendészeti Jogi Tanszék

Tamás SKORKA dr., police lieutenant-colonel, assistant lecturer, University of Public Service, Faculty of Law Enforcement, Department of Public and Law Enforcement https://orcid.org/0000-0002-2408-6158; Skorka.Tamas@uni-nke.hu

2 A 2020. évben azonosított új koronavírus (SARS-CoV-2) okozta fertôzések (COVID-19) megelőzésének és terápiájának kézikönyve. Emberi Erőforrások Minisztériuma, 2020. 4.
} 
14\%-ban súlyos lefolyású, míg a betegek 6\%-ánál kritikus helyzet alakul ki. A betegség súlyos formája leginkább a 60 évnél idősebbeket és a krónikus betegeket érinti. ${ }^{3}$

A lappangási idő 2-14 nap, gyógymódja nincs, csak a tünetek kezelése és a megelőzés, ami jelenleg megoldható. „A megfertőződést - a WHO ajánlása - szerint a higiéniai szabályok fokozott betartásával, gyakori és alapos kézmosással, fertőzött személyekkel való érintkezés elkerülésével, társadalmi távolságtartással stb. lehet elkerülni." ${ }^{4}$

A betegség természetének rövid ismertetése után mindenki számára érthetővé válhatnak a közelmúltban bevezetett olyan kormányzati intézkedések, mint például a szájmaszkviselésre kötelezés, a védőtávolság és a vásárlási idősávok bevezetése, a határellenőrzés visszaállítása vagy a 14 napos karantén elrendelése.

\section{Egy világjárvány kialakulása}

A közép-kínai Hupej tartományban található Vuhan város neve a közelmúltban a világ szinte minden részén ismertté vált. 2019. december 8-án itt diagnosztizálták először a koronavírus által terjesztett megbetegedést. Ettől az időponttól a fertőzés rohamosan terjedt a 11 milliós nagyvárosban, december végére pedig szinte az összes kínai tartományban megtalálható volt.

A kínai hatóságok - érzékelve a helyzet súlyát - a fertőzés megakadályozása érdekében a tartomány több nagyvárosát lezárták, a helyi és az országon belüli távolsági közlekedést korlátozták, katonai egészségügyi csoportot vezényeltek Vuhanba, két kórházat építettek - gyakorlatilag pillanatok alatt -, meghosszabbították a Kínai Holdújév miatti munka- és tanítási szünetet, a kínai falvakat permetező drónokkal fertőtlenítették, és nagy mennyiségú tájékoztató anyagot adtak ki az állampolgárok részére.

Mindezen intézkedések dacára a vírus a környező országokban is felütötte a fejét. Majd szép lassan az egész világon terjedésnek indult, és február hónap végére már szinte minden kontinensen volt fertőzött személy. A földünket behálózó légi közlekedési folyosók, amely egyébként a gazdaság, a kultúra, a társadalmi kapcsolatok fejlesztésének kiváló eszközei, most a vírus terjedésének az eszközeivé váltak. A turizmus az óceánjáró hajók révén vagy egy síparadicsom ${ }^{5}$ az Alpokban, mind-mind potenciális gócponttá váltak a vírus terjedésének korai szakaszában, amíg az egyes országok nem tették meg a szükséges intézkedéseket.

\footnotetext{
A 2020. évben azonositott új koronavirus (SARS-CoV-2) okozta fertőzések (COVID-19) megelőzésének és terápiájának kézikönyve. (2020) i. m. 4.

4 https://konzuliszolgalat.kormany.hu/koronavirus (A letöltés dátuma: 2020. 06. 18.)

5 Február 8-án újabb fertőzött személyeket találtak Franciaországban egy síparadicsomban. Mindnyájan brit állampolgárok voltak, akik egy Szingapúrból hazatért ismerősüktől kapták el, akivel ugyanabban a faházban laktak. Coronavirus: Five Britons in French ski chalet catch virus. 2020.
} 
A WHO január 30-án életbe léptette a világméretű egészségügyi vészhelyzetet, majd az események hatására 2020. március 11-én világjárvánnyá, pandémiává ${ }^{6}$ nyilvánította a Covid-19 koronavírus-járványt. ${ }^{7}$

Erre az időre a világjárvány egyik gócpontja Kínából Európába helyeződött át. Az európai országok stratégiájának lényege a járvány terjedésének lassításában és az egészségügyi rendszerek gyors felkészítésében fogalmazódott meg. Időt kell nyerni a várhatóan nagyszámú beteg ellátásának megszervezésére. Amíg nincs ellenszer, addig csak a tömeges szűrés, a kiszűrt fertőzöttek elkülönítése, kontaktjaik felkutatása és az a tájékoztatás adhat megoldást, amely megérteti az emberekkel a vírus által okozott veszély nagyságát, és elfogadtatja velük a végrehajtandó biztonsági intézkedéseket.

\section{A rendkívüli jogrend bevezetése Magyarországon}

A Kormány áttekintette a Kínai Népköztársaság területérôl indult koronavírus-járvány kapcsán kialakult helyzetet, és megállapította, hogy Magyarország polgárainak védelme érdekében elengedhetetlen az egészségügyi és járványügyi helyzet alakulásának fokozott figyelemmel kísérése, a szükség szerinti intézkedések hatékony megszervezése és mindezek érdekében az állami szervek tevékenységének összehangolása. ${ }^{8}$ A fenti feladat ellátására a Kormány Koronavírus-járvány Elleni Védekezésért Felelös Operatív Törzset ${ }^{9}$ (Operatív Törzs) állított fel, amely első ülését 2020. január 31-én tartotta. A felkészülés tehát megkezdődött, az első magyarországi fertőzött azonban még váratott magára. 2020. március 4-én két Magyarországon tanuló iráni állampolgárnál mutatták ki először a vírust.

2020. március 11-én a Covid-19 világjárvánnyá nyilvánításának napján a 40/2020. (III. 11.) Korm. rendelettel (40/2020. Korm. rendelet) Magyarországon is kihirdették a veszélyhelyzetet. Magyarország Alaptörvénye (Alaptörvény) rendelkezik a különleges jogrendről, amelynek egyik formája - a rendkívüli állapot, a szükségállapot, a megelőző védelmi helyzet, a terrorveszélyhelyzet, a váratlan támadás mellett - a veszélyhelyzet. Az Alaptörvény 53. cikke szerint: „A Kormány az élet- és vagyonbiztonságot veszélyeztető elemi csapás vagy ipari szerencsétlenség esetén, valamint ezek következményeinek az elhárítása érdekében veszélyhelyzetet hirdet ki."

A 40/2020. Korm. rendelettel a Kormány az Alaptörvény rendelkezéseinek megfelelően „az élet- és vagyonbiztonságot veszélyeztető tömeges megbetegedést okozó humánjárvány következményeinek elhárítása, a magyar állampolgárok egészségének

\footnotetext{
A pandémia (görög) olyan fertőző betegség okozta járvány, amely sok embert fertőz meg nagyon nagy területen, akár több kontinensen vagy világszerte. Hivatalosan az Egészségügyi Világszervezet (WHO) hirdethet pandémiát. Pandémia. Wikipédia, a szabad enciklopédia.

Covid-19-pandémia. Wikipédia, a szabad enciklopédia.

1012/2020. (I. 31.) Korm. határozat a Koronavírus-járvány Elleni Védekezésért Felelős Operatív Törzs felállításáról.

Az Operatív Törzset a belügyminiszter az emberi erőforrások minisztere bevonásával vezeti. Az Operatív Törzs tagjai: a belügyminiszter, az emberi erőforrások minisztere, a BM közbiztonsági főigazgatója, az országos rendőr-főkapitány, az Állami Egészségügyi Ellátó Központ főigazgatója, a Dél-Pesti Centrumkórház Országos Hematológiai és Infektológiai Intézet főigazgatója, az OIF főiigazgatója, az OKF főigazgatója, az OMSZ főigazgatója, az országos tisztifőorvos, a TEK főigazgatója.
} 
és életének megóvása érdekében Magyarország egész területére veszélyhelyzetet" hirdetett ki.

Alapesetben a Kormány az Alaptörvény szerint feladatkörében eljárva, törvényben nem szabályozott tárgykörben, illetve törvényben kapott felhatalmazás alapján rendeletet alkothat. ${ }^{10} \mathrm{~A}$ veszélyhelyzetben történő rendeletalkotás viszont ennél szélesebb körű. A veszélyhelyzetben alkotott rendelet - sarkalatos törvényben meghatározottak szerint - egyes törvények alkalmazását felfüggesztheti, törvényi rendelkezésektől eltérhet, ezenfelül pedig a kormány egyéb rendkívüli intézkedések meghozatalára is jogosult.

A rendelet időbeli hatálya is eltérő a veszélyhelyzetben. A rendelet 15 napig marad hatályban, kivéve, ha a kormány - az országgyúlés felhatalmazása alapján - a rendelet hatályát meghosszabbítja. A koronavírus elleni védekezésről szóló 2020. évi XII. törvényt ezen okból is nevezik „felhatalmazási törvénynek”, mert a kormányrendeletek hatályát a veszélyhelyzet megszúnéséig meghosszabbította. ${ }^{11}$

A Kormány döntése alapján 2020. június 18-án megszűnt a veszélyhelyzet, helyette egészségügyi válsághelyzetet hirdettek ki. A 2020. évi LVII. törvény bevezetője szerint a Covid-19-fertőzés okozta humán járvány megelőzésére, illetve következményeinek elhárítására hozott gyors és hatékony rendkívüli intézkedések meghozták eredményüket, így indokolatlan a veszélyhelyzet további fenntartása, ezért az Országgyúlés felhívta a Kormányt a veszélyhelyzet kihirdetéséről szóló 40/2020. Korm. rendelet szerinti veszélyhelyzet Alaptörvény 54. cikk (3) bekezdése szerinti megszüntetésére.

\section{Az alapvető jogok korlátozása}

A veszélyhelyzet tartama alatt a hatalmi ágak közötti egyensúly bizonyos mértékben a végrehajtó hatalom, a kormányzat irányába tolódik el. Ez az eltolódás azonban idejében és tartamában is korlátozott, alkotmányosan körülbástyázott. Az alaptörvény a különleges jogrend idejére - a kivételek megjelölésével - alapvető jogok gyakorlását is felfüggesztheti, illetve korlátozhatja. ${ }^{12}$ Vannak jogok, amelyek még a különleges jogrend esetén sem korlátozhatók, ilyenek például az élethez, emberi méltósághoz való jog, a jogorvoslati jog vagy a védelemhez való jog, érvényre kell jutnia az ártatlanság vélelmének, míg tilalmazott a kínzás, az embertelen megalázó bánásmód alkalmazása. ${ }^{13}$

A korlátozást nem tűrő jogokon túl bizonyos jogok gyakorlása felfüggeszthető, illetve az Alaptörvényben meghatározott módon korlátozható. ${ }^{14} \mathrm{~A}$ felhatalmazási törvény

\footnotetext{
Magyarország Alaptörvénye 15. cikk (3) bek.

2020. évi XII. törvény a koronavírus elleni védekezésről 3. § (1) bek.

Alaptörvény 54. cikk (1) bek.

Az Alaptörvény II. és a III. cikkében, valamint a XXVIII. cikk (2)-(6) bekezdésben megállapított alapvető jogok.

14 Alaptörvény I. cikk (3) bek. Az alapvető jogokra és kötelezettségekre vonatkozó szabályokat törvény állapítja meg. Alapvető jog más alapvető jog érvényesülése vagy valamely alkotmányos érték védelme érdekében, a feltétlenül szükséges mértékben, az elérni kívánt céllal arányosan, az alapvető jog lényeges tartalmának tiszteletben tartásával korlátozható.
} 
az Alaptörvénnyel összhangban rögzíti, hogy a kormány intézkedései csak a szükséges mértékben, az elérni kívánt céllal arányosan járhatnak jogkorlátozással. Egyébként maga a felhatalmazási törvény is él a jogok korlátozásának lehetőségével, amikor az időközi választások kitúzését, megtartását, illetve az országos és helyi népszavazás kezdeményezését tilalmazza a veszélyhelyzet időtartamát követő 15 napig. ${ }^{15}$

Az elérni kívánt cél a vírus terjedésének lelassítása, amelyet az emberek közötti biztonságos távolság fenntartásával lehet megvalósítani. A Kormány ezért felülvizsgálta a mindennapi élet azon színtereit, amelyek nagyobb létszámú embert koncentrálnak szűk területre, így lehetővé téve a vírus terjedését, majd e helyek látogatását megtiltotta. A 46/2020. (III. 16.) Korm. rendelet (46/2020. Korm. rendelet) több ponton is korlátozta a szabad mozgás és a tartózkodási hely szabad megválasztásának jogát. A vendéglátó üzletekben, a zenés táncos rendezvények helyszínén, az előadó-művészet valamennyi ágának fellépése céljából megtartott eseményeken, de a közgyüjteményekben, közművelődési intézetekben is megtiltotta a tartózkodást. A rendeleti úton történő alapjogkorlátozás tipikus példája a kijárási korlátozásról szóló 71/2020. (III. 27.) Korm. rendelet (71/2020. Korm. rendelet). A lakóhely, a tartózkodási hely, illetve a magánlakás elhagyására csak a rendeletben meghatározott alapos indokkal kerülhetett sor.

A rendvédelmi szervek állományába tartozók, a katonák és honvédelmi alkalmazottak, az egészségügyi dolgozók munkájára a veszélyhelyzet időszakában fokozottan szüksége van a társadalomnak, ezért az ő alkotmányos jogaik is korlátozás alá kerültek, ${ }^{16}$ amikor kormányrendelet útján meghatározták, hogy Magyarország területét csak az ágazat irányításáért felelős miniszter külön engedélyével hagyhatják el. ${ }^{17}$

A különleges jogrend a szabad mozgás jogán kívül korlátozta még a gyülekezéshez való jogot a helyszínen tartózkodás tiltásával, ${ }^{18}$ a vállalkozáshoz való jogot a nyitvatartási idők és életkori idősávok bevezetésével, az oktatáshoz való jogot az oktatási intézmények látogatásának korlátozásával ${ }^{19}$ és mindezeken túl az élet számtalan más területén is korlátozta az állampolgárok jogait.

„A Covid-19 járvány eddig példátlan kihívás elé állította hazánkat és a világ valamennyi országát. A hagyományos eszközök és megoldások alkalmatlannak bizonyultak a járvánnyal szembeni egészségügyi és gazdasági védekezés során. Alkotmányos hagyományaiknak és a járványügyi helyzetnek megfelelően valamennyi állam speciális intézkedéseket hozott, hogy sikerrel léphessen fel a válsághelyzet kezelése érdekében." ${ }^{20}$

A felhatalmazási törvénynek köszönhetően Magyarország kormánya gyors és hatékony intézkedéseket tudott hozni, amelyek - a fentiekben láthattuk - korlátozták ugyan az alapjogokat, de ezen intézkedések szükségességét és arányosságát igazolja

\footnotetext{
2020. évi XII. törvény a koronavírus elleni védekezésről 6. § (2)-(3) bek.

16 A jogkorlátozások „általános” lehetőségei kapcsán lásd részletesen: Szilvásy György Péter: A rendészet jogi szabályozása Magyarországon. In Szigeti Péter - Szilvásy György Péter: Rendészet és emberi jogok. Budapest, Rejtjel, 2015. 66-68.

17 41/2020. (III. 11.) Korm. rendelet 6. § (1) bek.

18 46/2020. (III. 16.) Korm. rendelet 4. § (1) bek.

19 41/2020. (III. 11.) Korm. rendelet 4. § b) pont.

20 T/10747. számú törvényjavaslat indokolással - a veszélyhelyzet megszüntetéséről.
} 
az a tény, hogy hazánkban a járvány hatásai nem öltöttek olyan drasztikus mértéket, mint több más országban.

\section{Rendeleti szabályozás}

A netjogtár sajátos gyűjteményt tett közzé, amelyben a veszélyhelyzettel kapcsolatos joganyagot gyüjtötte össze. A címszó alatt 2020. június 18-án 348 tétel szerepelt. Ebben megtalálhatóak a honi jogalkotás remekei mellett az EU szerveinek aktusai is. Az Európai Parlament és a Tanács rendeletei, határozatai, a Bizottság határozatai, rendeletei, közleményei, amelyekkel az egységes és ezáltal hatékonyabb európai védekezést segítik elő. A koronavírus elleni védekezést azonban minden ország saját maga dolgozza ki. A magyar kormány élve az országgyúlés adta felhatalmazással, rendeleti úton szervezte a védekezést, amelynek ékes bizonyítéka, hogy a fenti listából 162 tételt a kormányrendeletek tesznek ki.

A feladat roppant sokrétü, hiszen az élet minden területét érinti a Covid-19-fertőzés okozta tömeges megbetegedést okozó humán járvány. Az elsődleges cél a Covid-19-fertőzés elterjedésének akadályozása, lassítása, az emberi élet, egészség megóvása, míg a későbbiekben az országot sújtó negatív gazdasági hatások enyhítése. A célok elérése érdekében a közösségi érintkezés színtereit kellett sorra venni és korlátozásokat bevezetni. Így került sor - többek között - az óvodák, iskolák bezárására, a határok lezárására, a rendezvények, illetve a sportélet korlátozására, a hivatali ügyintézés újragondolására, a védőfelszerelés használatának szabályozására és persze a gazdaságvédelmi intézkedésekre: a bértámogatásokra, a hitelmoratóriumra, a járulékfizetési könnyítések bevezetésére, pályázatok kiírására.

A továbbiakban ebből a tetemes joganyagból azokat a rendeleteket kívánom elemezni, amelyek a rendőrség munkájával, illetve a szabálysértési joggal kapcsolódnak össze.

A veszélyhelyzet kihirdetéséről szóló 40/2020. Korm. rendelet 3. § (1) bekezdése rögzíti, hogy „[a] veszélyhelyzettel kapcsolatos rendkívüli intézkedésekről külön kormányrendeletek rendelkeznek".

E rendeletek sorát az élet- és vagyonbiztonságot veszélyeztető tömeges megbetegedést okozó humán járvány megelőzése, illetve következményeinek elhárítása, a magyar állampolgárok egészségének és életének megóvása érdekében elrendelt veszélyhelyzet során teendő intézkedésekről szóló 41/2020. (III. 11.) Korm. rendelet (41/2020. Korm. rendelet) nyitja.

\subsubsection{1/2020. (III. 11.) Korm. rendelet}

A Kormány a vírus terjedésének március eleji helyzetét tekintve hozta meg döntését, figyelembe véve azt, hogy honnan indult ki a fertőzés, mely országokban terjedt tovább, 
hol vannak azok a gócpontok, ahonnét a fertőzés Magyarországot veszélyezteti. Az operatív helyzet értékelését követően azt a döntést szövegezték meg, hogy az Olasz Köztársaság, a Kínai Népköztársaság, a Koreai Köztársaság és az Iráni Iszlám Köztársaság területéről nemzetközi személyszállítást végző vasúti jármű, autóbusz, polgári légi jármű Magyarország területére nem léphet, illetve az ezen országokból érkező nem magyar állampolgárok személyforgalomban Magyarország területére nem léphetnek be. ${ }^{21} \mathrm{Te}$ kintettel arra, hogy Észak-Olaszország - a nagyszámú kínai bevándorló, az elöregedő társadalom és a jelentős mértékű turizmus miatt is - az egyik leginkább járvány sújtotta terület lett Európában, és amely közelsége miatt fokozott kockázatot jelentett a járvány terjedése tekintetében, a Kormány intézkedett a szlovén és osztrák határon a határfogalom-ellenőrzés ideiglenes visszaállítására is.

Az Alaptörvény rendelkezése alapján a magyar állampolgár (külföldről) bármikor hazatérhet, ${ }^{22}$ így a beutazási tilalommal érintett országokból is. A hazatérést követően azonban egészségügyi vizsgálat eltűrésére kötelezett. Covid-19-fertőzés gyanúja esetén kijelölt karanténban helyezik el, ha nincs gyanúok (láz, köhögés stb.), akkor a lakóhelyen kell egy 14 napos járványügyi megfigyelést „elszenvedni”.

A rendelet a fentiekkel összhangban felfüggeszti a Külföldi Nyelvtanulási Programokat és megtiltja a külföldre irányuló iskolai kirándulásokat is.

Szabálysértési szempontból mindenképp megemlítendő a 41/2020. Korm. rendelet 4. § a) pontja: „[A] magyar állampolgárok Magyarország területén hatályos, lejáró hivatalos okmányai a veszélyhelyzet megszűnését követő 15 napig érvényesek”. Felmerül a kérdés, hogy a hivatalos okmány megjelölés mit takar valójában? A BM Kommunikációs Főosztály tájékoztatása szerint idetartozik a személyazonosító igazolvány, a vezetői engedély, a forgalmi engedély, valamint a mozgásában korlátozott személy parkolási igazolványa is. ${ }^{23}$ Fontos tisztázni az okmányok körét, mert így több szabálysértési tényállás is érintett lehet. Ha a magyar állampolgár tulajdonosa/üzembentartója a gépjármünek, amelynek lejárt a műszaki érvényessége (forgalmi engedélye), akkor közlekedése során megvalósítja ugyan a szabálysértésekről, a szabálysértési eljárásról és a szabálysértési nyilvántartási rendszerről szóló 2012. évi II. törvény (Szabs tv.) 221. §-a szerint minősülő „Érvénytelen hatósági engedéllyel vagy jelzéssel való közlekedés” szabálysértést, de mivel büntethetőséget kizáró ok áll fenn, vagy el kell utasítani a feljelentést, vagy meg kell szüntetni az eljárást. Ugyanez a helyzet, ha a vezetői engedély orvosi érvényessége jár le a veszélyhelyzet időtartama alatt. A közúti közlekedési igazgatási feladatokról, a közúti közlekedési okmányok kiadásáról és visszavonásáról szóló 326/2011. (XII. 28.) Korm. rendelet 5. § (5) bekezdés a) pontjába ütköző és a Szabs tv. 225. § (1) bekezdése szerint minősülő „Közúti közlekedési igazgatási szabályok megsértése” szabálysértést valósítja meg az állampolgár, a felelősségre vonás azonban ebben az esetben is elmarad.

A 41/2020. Korm. rendelet 2020. március 12-től március 27-ig volt hatályban. 2020. április 2. napján azonban hatályba lépett az egészség és élet megóvása, valamint

\footnotetext{
41/2020. (III. 11.) Korm. rendelet 2. §.

Alaptörvény XIV. cikk (2) bek.

3 Pulai László: A BM válaszolt: lehet müszakiztatni, de nem muszáj. 2020.
} 
a nemzetgazdaság helyreállítása érdekében elrendelt veszélyhelyzettel kapcsolatos rendkívüli intézkedésekről szóló 81/2020. (IV. 1.) Korm. rendelet (81/2020. Korm. rendelet), amelynek 6. §-a a fenti szabályt ismét életbe léptette. A rendőrség honlapján közzétett tájékoztatás szerint: „A 2020. március 27. és április 1. közötti időtartamban lejáró okmányok tekintetében az érintett ügyfeleket szankciók nem érhetik, az ő esetükben az okmányok meghosszabbítására szintén a veszélyhelyzet megszűnése után kell intézkedni." 24

Az ORFK adatai alapján a közlekedési szabálysértések miatt feljelentett személyek száma -76 956 fő - és a vizsgált baleseti ügyek száma - 10521 ügy - az elmúlt tíz év adatait tekintve 2020. I-V. hónapjában a legalacsonyabb. ${ }^{25}$ Feltehetően nem csak az előbb ismertetett szabályozásnak, mindinkább a kijárási korlátozásnak és a beutazási korlátozásoknak, valamint az egyébként is folyamatosan csökkenő szabálysértési ügyszámnak tudható be ez a kedvező statisztikai adat.

\section{Határforgalom-ellenőrzés a veszélyhelyzet időtartama alatt - teherforgalom}

Az hamar egyértelművé vált, hogy a vírus terjedését minden lehetséges eszközzel lassítani, akadályozni kell. A vírus - a gócpontjának számító Kínából - néhány órás repülőúttal a világ bármely részét, így Magyarországot is elérheti. Fontos lett tehát a határok lezárása, a határforgalom-ellenőrzés visszaállítása a „belső határokon” is. A teljes zárásra azonban a kereskedelmi-gazdasági-társadalmi kapcsolatok miatt nem kerülhetett sor.

Az Európai Bizottság 2020. március 16-án olyan iránymutatásokat fogalmazott meg a határigazgatási intézkedésekre vonatkozóan, amelyek az egészség védelme mellett biztosítják a belső határok átjárhatóságát az áruk és az alapvető szolgáltatások előtt. Az európai ellátási lánc, a szárazföldi, tengeri és légi fuvarozási szolgáltatások folyamatos és megszakítás nélküli múködtetése révén stratégiai szempontból kulcsfontosságú az EU számára. A szárazföldi ellátás $75 \%$-a közúton történik. ${ }^{26} \mathrm{~A}$ tagállamoknak tehát a szomszédos országokkal egyeztetve a transzeurópai közlekedési hálózat (TEN-T) valamennyi érintett határátkelőhelyét úgynevezett „zöld sávos határátkelőként” meg kellett nyitniuk. Felfüggesztették a szállítmányozást érintő korlátozásokat, tilalmakat (például „kamion stop”), a közlekedési dolgozók számára állampolgárságtól, lakóhelytől függetlenül lehetővé vált a „belső határok” átlépése. A szomszédos országoknak egyeztetniük kellett, hogy az egészségügyi vizsgálatot a határ melyik oldalán végzik el, mert a várakozási idők csökkentése érdekében - az iránymutatás alapján - csak az egyik oldalon

Ügyféltájékoztató. Rendőrség.

2010-2020. évek közötti időszak statisztikai kimutatása. Igazgatásrendészeti szakterület. Országos Rendőr-főkapitányság Rendészeti Főigazgatóság.

26 A Bizottság (2020/C 96 I/01) közleménye a zöld sávoknak az egészség védelmét, valamint az áruk és az alapvető szolgáltatások rendelkezésre állását biztosító határigazgatási intézkedésekre vonatkozó iránymutatások szerinti végrehajtásáról. 
végezhető szűrés. Az ellenőrzés a testhőmérséklet ellenőrzésén alapul, tekintve, hogy a betegek 88\%-a lázas, tehát ez a leggyakoribb tünete a fertőzésnek. A higiéniai előírások fokozott betartása mellett a jármúvezetők nem rakodhatnak, a határforgalomellenőrzéskor lehetőség szerint a járműben maradnak, lejárt engedélyeik érvényesnek tekintendők, illetve mentesülnek a karantén alól (!) is.

Rendészeti szempontból a legfontosabb intézkedés a közlekedési folyosók, tranzit útvonalak létrehozása volt. A határok „zárása” nem várt és a Schengeni térség létrehozása óta - kivéve a közelmúlt migrációs mozgásai és ellenük tett intézkedéseket, amelyek azonban az unió polgárait nem érintették - szinte példátlan esemény volt, amely érdekes helyzetet teremtett. A saját állampolgárok mellett a Magyarországgal szomszédos országok polgárai is nagy számban vállaltak munkát Nyugat-Európában. Ez a több százezer ember folyamatosan és szinte észrevétlenül ingázott kelet és nyugat között. A határok zárásával hónapokra szétszakadtak a családok, hazájukban rekedtek a külföldön munkát vállalók. Utazni nem, vagy csak a határátlépést követően országonként 14 napos karantén mellett lehetett, és a korlátozások időtartama alá esett a húsvéti ünnep is, amely hagyományosan nagy utasmozgásokat generál.

A fenti helyzet orvoslására a szomszédos országokkal kötött megállapodásokat követően az egészség és élet megóvása, valamint a nemzetgazdaság helyreállítása érdekében elrendelt veszélyhelyzettel kapcsolatos rendkívüli intézkedésekről szóló 81/2020. Korm. rendelet 4 . $\S$ (2) bekezdésében kapott felhatalmazás alapján az országos rendőrfőkapitány a szomszédos állam polgárai esetében, valamint a humanitárius célból történő tranzitáthaladás során a határátlépésre, a Magyarország területén tartózkodásra, az áthaladásra, az útvonalra, a megállási lehetőségekre, a humanitárius tranzitforgalomra vonatkozó különös közlekedésre vonatkozóan határozatot hozott, amelyet a Hivatalos Értesítő 2020/17. számában tettek közzé.

Tehát a Nyugat-Európából hazatérő román, ukrán, szerb állampolgárok Hegyeshalomnál beléptek Magyarország területére, majd az M1-es autópályán végighaladva a szerbek és a románok az M5-ös autópályán Röszkén, illetve Nagylakon, míg az ukránok az M3-as autópályán közlekedve Záhonynál hagyták el az ország területét. A belépést természetesen egészségügyi szűrés előzte meg. Az áthaladás során az autópályáról tilos volt a letérés, megállásra pedig csak a kijelölt benzinkutakon volt lehetőség. A járműveket és a benzinkutakat is jól látható matricával jelölték meg. Az áthaladásra időablakokat határoztak meg a torlódások elkerülése érdekében.

Mindezen intézkedések ellenére az Európai Bizottság iránymutatása, amely szerint a „zöld sávos határátkelőhelyeken” való áthaladás - beleértve az ellenőrzéseket és a szűrővizsgálatokat is - nem haladhatja meg a 15 percet, nem volt tartható. Magyarország államhatára 2215,3km hosszú, ebből 1111,7km-en, a schengeni belső határon kellett visszaállítani a határforgalom-ellenőrzést. Magyarország államhatárának felén! A Schengeni belső határon 84 határátkelőhelyen - van közöttük időszakosan nyitva tartó, vagy csak személyforgalom számára megnyitott is - áramlott a forgalom a vírusmentes időszakban. A határforgalom-ellenőrzés visszaállítása és az utazási korlátozások bevezetése kapcsán a határátkelőhelyek jelentős részét lezárták. 2020. május 5-én 
25 közúti határátkelőhely múködött a 84-ből. A schengeni külső határon 35 közúti határátkelőhelyből 21 volt megnyitva a forgalom számára és a nyitott határátkelőhelyeken is korlátozások voltak érvényben, például a román viszonylatban lévő Kiszombor Közúti Határátkelőhelyen a belépő személyforgalomban csak magyar állampolgár, nemzetközi teherforgalom 7,5 t korlátozással, illetve az ingázók léphették át az államhatárt. Bár a személyforgalom csökkent, de a határátkelőhely-lezárások és a bevezetett egészségügyi ellenőrzések miatt folyamatossá váltak a torlódások a határátkelőhelyeken. Csanádpalotán nem ritkán 10 km-es kamionsorok torlódtak fel három-négy órás várakozási időkkel.

A teherforgalom torlódásának csökkentése érdekében a szomszédos országok határforgalom-ellenőrzést végző szerveinek folyamatosan egyeztetniük kellett egymással. A határforgalom-ellenőrzés koordinálására az ORFK-n külön törzset állítottak fel. A törzs kontrollálta a határvárakozásokat, szervezte a magyar állampolgárok hazatérését, a külföldi állampolgárok tranzit áthaladását, az élőállat-, illetve az egészségügyi szállítmányok soronkívüliségét, a felelős vezetői döntések meghozatalához szükséges statisztikai adatokat gyűjtötte, és gyakran ügyfélszolgálatként müködött a határátlépéssel kapcsolatos telefonos megkeresések tekintetében.

\section{81/2020. (IV. 1.) Korm. rendelet - a személyek szabad áramlása?}

A teherforgalom biztosításán túl a személyforgalomban bevezetett korlátozások is jelentős terhet róttak a rendészeti szervekre, kiemelten a rendőrségre.

Amíg a 41/2020. Korm. rendelet csak az Olasz Köztársaság, a Kínai Népköztársaság, a Koreai Köztársaság és az Iráni Iszlám Köztársaság területéről érkező személyszállítást végző járművek, illetve az onnan érkező nem magyar állampolgárok beléptetését tagadta meg Magyarország területére, addig a 81/2020. Korm. rendelet függetlenül a kiindulási országtól megtiltotta a külföldiek beutazását hazánkba, a hazatérő magyar állampolgárok esetében pedig kötelező egészségügyi vizsgálatot és karantént írt elő. E szigorú szabályozás alól - meghatározott feltételek teljesülése esetén - kivételt képeztek a Magyarország területén áthaladó katonai konvojok és a különös méltánylást érdemlő esetek, amelyekben a rendészeti országos rendőrfőkapitány-helyettes felmentést adhatott a beutazási tilalom alól, és egyedi magatartási szabályt állapíthatott meg a kérelmező részére. A kivételek harmadik csoportját az országos rendőrfőkapitány alkotta szabályok jelentették, amelyek a szomszédos országok állampolgárainak beutazására, illetve a humanitárius célú tranzitálásra vonatkoztak. ${ }^{27}$

Az országos rendőrfőkapitány a 81/2020. Korm. rendelet 4. § (2) bekezdése adta hatáskörében, 29000/9828/2020.ált. számon hozott határozatot, hogy a szomszédos államokkal létrejött megállapodás alapján, az azokban meghatározott célból és feltételek

81/2020. (IV. 1.) Korm. rendelet 2-4 §. 
igazolásával biztosítható a szomszédos állam polgárainak belépése. ${ }^{28} \mathrm{~A}$ megállapodások tipikus példája az ingázás. Az ingázási célból szomszédos országba távozott, majd onnan hazatérő személy beléptetése - karantén elrendelése nélkül - biztosított. Az ingázási célú határátlépés indoka lehet munkavégzés, egészségügyi ellátás, oktatási intézmény látogatása. A határátkelőhelyen a munkavégzéshez kapcsolódó munkáltatói igazolás, a megművelt földterület tulajdonjogának/használati jogának igazolására szolgáló okirat, iskolalátogatási igazolás, leckekönyv, illetve a lakhelyet igazoló lakcímkártya felmutatása szükséges. A lakcímellenőrzés azért szükséges, mivel a megállapodások az államhatártól számított eltérő mélységû területsávra vonatkoznak. A legtöbb szomszédos ország esetében 30 km-es területsávon belül lakó személyek ingázhatnak, de Szerbiánál ez 50 km, míg Ausztria 2020. április 1-jén feloldotta a területi korlátozást és egész területére nézve lehetővé tette a magyar állampolgárok munkavégzési célú beutazását.

A határforgalom-ellenőrzést végző szerveknél feladatként jelentkezett az érettségi vizsga céljából Magyarországra érkező diákok beléptetése, tekintve, hogy a 2020. május 4-től 21-ig tartó vizsgák ${ }^{29}$ időpontjában még utazási korlátozások voltak érvényben. $\mathrm{Az}$ országos rendőr-főkapitányság szakmai iránymutatása alapján az érettségi vizsga napján, valamint az azt megelőző, illetve azt követő két napban az érettségiző és egy fő kísérő - méltányossági kérelem nélkül, mentesülve a karantén alól - útiokmány és az érettségi vizsgáról szóló igazolás birtokában átléphette az államhatárt.

A beutazási tilalom a diplomáciai mentességet élvező személyeket nem érintette. Ha az egészségügyi vizsgálat nem állapította meg Covid-19-fertőzés gyanúját, akkor tekintettel a mentességre, korlátozás nélkül biztosítani kellett a beléptetést. A külképviseletek diplomáciai személyzetének nemzetközi jog alapján kiváltságokkal és mentességekkel nem rendelkező hozzátartozói vagy a diplomáciai képviselet személyzetéhez nem tartozó munkatársainak beléptetéséhez a rendészeti országos rendőrfőkapitány-helyettes adhatott felmentést a diplomáciai képviselet erre irányuló megkeresése alapján. A diplomáciai képviseletek a külföldön rekedt saját állampolgárok hazautazását is szervezték. Ennek során folyamatosan együttmüködtek a magyar hatóságokkal. ${ }^{30} \mathrm{~A}$ hazautaztatás során a legkülönfélébb élethelyzetek álltak elő. A Kolumbiai Nagykövetség például egy humanitárius repülőjáratot indított Németországból, és erre a járatra kellett feljuttatni a Szerbiában lévő kolumbiai állampolgárt úgy, hogy Magyarországra beléptetve, Budapesten szállt vonatra müncheni úticéllal.

A fő szabálytól eltérően nem magyar állampolgárokat is beléptettek a tilalom időtartama alatt. A magyar állampolgárok magyar állampolgársággal nem rendelkező családtagjai, ha tartózkodási engedéllyel rendelkeztek, vagy Magyarországon kötöttek házasságot, és ennek tényét az Országos Idegenrendészeti Főigazgatóság (OIF) a nyilvántartásokban történő ellenőrzést követően megerősítette, beléphettek az ország területére.

28 Hivatalos Értesítő, 17. sz.

29 119/2020. (IV. 16.) Korm. rendelet a veszélyhelyzet során az érettségi vizsgák 2020. május-júniusi vizsgaidőszakban történő megszervezéséről 2. § (2) bek.

30 ORFK Rendészeti Főigazgatóság Határrendészeti Főosztály. 
A határok zárása, a személyforgalom korlátozása károsan hatott a gazdasági életre. Vállalkozások zártak be, munkavállalók elbocsátására, részmunkaidős foglalkoztatására került sor. A szomszédos országokkal folytatott élénk gazdasági kapcsolat is megbénult. A 174/2020. (IV. 30.) Korm. rendelet a nemzetgazdaság helyreállításának elősegítése érdekében 2020. május 1-jei hatállyal módosította a 81/2020. Korm. rendeletet lehetővé téve a Visegrádi négyek, a Koreai Köztársaság, Németország és Ausztria között az üzleti célú utazásokat. ${ }^{31}$

Hasonló célzattal született meg a 185/2020. (V. 6.) Korm. rendelet is, amely az agrárgazdaság munkaerőigényét próbálta biztosítani a külföldi munkavállaló Magyarországra való beléptetésével. Az agrárágazatban dolgozók csak az országos rendőrfőkapitány által megjelölt határátkelőhelyeken léphették át az államhatárt, ha a belépés előtt legalább 48 órával a munkáltató a megfelelő információkat elektronikus úton eljuttatta a kijelölt és igénybe venni kívánt határátkelőhely szerint illetékes határrendészeti kirendeltségre. $^{32}$

A külföldről érkező nem magyar állampolgárok nem léphetnek be az ország területére - a fenti kivételektől eltekintve -, míg a magyar állampolgárok az egészségügyi szűrés eredményeképpen 14 napra vagy karanténba vagy hatósági házi karanténba kerülnek. Ha a hazatérő magyar állampolgár Covid-19-fertőzésből gyógyult, és a fertőzés tüneteit nem mutatja, vagy a belépést megelőzően legalább 14 napig járványügyi megfigyelés hatálya alatt állt, mentesül a karantén alól. ${ }^{33} \mathrm{Az}$ „önkéntes karantén”, tehát az, hogy a hazautazás tervezett időpontját megelőzően már hetek óta nem mozdult ki a külföldön lévő lakóhelyéről, tartózkodási helyéről honfitársunk, az nem minősül járványügyi megfigyelésnek vagy karanténnak, tehát a hazatérést követően ezekre a magyar állampolgároknak is a kötelező 14 nap várt.

\section{Határátlépés méltányosságból}

A fenti szigorú szabályok alól azonban a 81/2020. Korm. rendelet 4. § (1) bekezdése alapján - különös méltánylást érdemlő esetben - a rendészeti országos rendőrfőkapitány-helyettes felmentést adhat, illetve egyedi magatartási szabályt állapíthat meg, ha az egészségügyi vizsgálat nem állapította meg fertőzés gyanúját és az érintettet a kijelölt karantén, valamint a hatósági házi karantén idejére nyilvántartásba vették. 


\subsection{A méltányosság}

„A méltányosság lényege [...], hogy a közigazgatási szerv a jogszabály felhatalmazása alapján a fél javára eltekinthet a jogszabályban foglaltak érvényesítésétől." ${ }^{34} \mathrm{~A}$ jogirodalom jogalkalmazói és jogalkotói méltányosságot különböztet meg, de a jogalkotói méltányosság is a jogalkalmazó szerv konkrét döntésével jelenik meg. A jogalkotói méltányosság jelen esetben azt jelenti, hogy a jogszabály maga ad felhatalmazást valamely rendelkezése alóli felmentésre (beutazási tilalom), illetóleg valamely jogszabály rendelkezésének kedvezőbb alkalmazására (egyedi magatartási szabály). „A jogszabályi felhatalmazásnak mindig kifejezettnek kell lennie, és helyes, ha a jogalkotó legalább példálózó felsorolással eligazít a méltányossági körülményekrôl." ${ }^{35} \mathrm{~A}$ rendészeti országos rendőrfókapitány-helyettes, Dr. Halmosi Zsolt $r$. vezérôrnagy úr a beléptetésre vonatkozó méltányossági jogkör gyakorlására a 81/2020. Korm. rendelet hatálybalépésével kapott jogkört, míg a fent említett példálózó felsorolást tartalmazó közleményt 2020. május 11-én tették közzé. Ebben az időszakban már napi szinten több száz beadványt bíráltak el.

Az országos rendőrfőkapitány 29000/12535-1/2020. ált. számú határozatában a méltányossági döntés iránti kérelem formai és tartalmi követelményeit egyaránt rögzítette. A kérelmet magyar és nem magyar állampolgárok egyaránt benyújthatták. A fókapitányi döntés szerint a kérelem csak magyar nyelven nyújtható be. Ez a döntés felvetheti az anyanyelvhasználati jog sérelmét. A gyakorlat azonban azt mutatta, hogy - a kérelmek tárgyából kifolyólag - a döntéseket rövid határidővel indokolt meghozni. Egy szülei temetésére külföldről hazatérő gyermek vagy egy végső stádiumban lévő közeli hozzátartozóval való utolsó találkozás, esetleg egy sürgős orvosi beavatkozás nem kaphat 30 napos ügyintézési határidőt a döntés meghozatala érdekében. Nincs idő tehát fordító kirendelésére, költségmegállapító határozat „jogerőzésére” stb. A rendkívüli jogrendben bizonyos jogok korlátozhatók. Megjegyzem, a kérelmeket átlagosan 1-3 nap alatt bírálták el, ezáltal a jogintézmény hatékonyan tudta ellátni rendeltetését.

A kérelembenyújtás módját is szabályozták, a korábbi e-mail-címre megküldött változó tartalmú és minőségú kérelmek helyett cégkapuról/ügyfélkapuról, illetve ezek hiányában a rendőrség internetes honlapján elérhető intelligens ûrlap kitöltésével és beküldésével lehetett kérelmet benyújtani ${ }^{36} \mathrm{E}$ két intézkedés bevezetése kiszürte az olyan kérelmek benyújtását, amelyek igazából nem tartoztak a méltányosság tartalmi körébe, csak adott esetben a kényszer szülte ôket. Megtörtént, hogy a magyar-osztrák határon várakozó külföldi mobiltelefonjáról küldött tört angolsággal néhány soros üzenetet az ugyfelszolgalat@orfk.police.hu e-mail-címre, majd az üzenet elküldését követően felháborodva hívta az ORFK Törzset, hogy mikor hajlandóak végre elbírálni a kérelmét. $\mathrm{Az}$ adatlapos kérelem benyújtása kiküszöbölte a hiányosan benyújtott kérelmek elbírálása

34 Szalai András: A közigazgatási jog alapjai. Budapest, Dialóg Campus, 2018. 102.

35 Patyi András: A közigazgatási müködés jogi alapjai. A magyar közigazgatás és közigazgatási jog általános tanai II. kötet. Budapest, Dialóg Campus, 2017. 179.

36 194/2020. (V. 11.) Korm. rendelet a különös méltányossági jog gyakorlásának rendjéröl 1. §. 
okozta nehézségeket is. A kérelemben valószínűsíteni kell a különös méltánylást érdemlő körülményeket, meg kell nevezni az érintett személyazonosításra alkalmas, az államhatár átlépéséhez felhasználni kívánt okmányt, és meg kell adni az okmányazonosító számát, valamint csatolni kell - amennyiben az a kérelem indokára figyelemmel lehetséges - a kérelem különös méltánylást érdemlő elbírálásának indokát igazoló irat másolatát, szükséges esetben a meghatalmazást. „A tartalmi vagy formai követelményeknek nem megfelelő - így különösen a nem magyar nyelven, a hiányosan, a kérelem méltányos elbírálásának indokát nem tartalmazó, azt nem valószínűsítő, nem személyesen történő eljárás esetén a meghatalmazás nélkül benyújtott - kérelem érdemi vizsgálat nélkül elutasítást von maga után." ${ }^{37}$ Ezzel gyakorlatilag megszűnt a hiánypótlásra felhívás kötelezettsége!

A méltányosságon alapuló beléptetés indokai között szerepel a fent említett példákon túl a magyar hatóságok előtt folyó eljárásokban való részvételt igazoló okirat (idézés), a nemzetgazdasági vagy közegészségügyi célból indokolt beutazás, a hallgatói vagy tanulói jogviszony alapján fennálló kötelezettségek teljesítése és a fuvarozási tevékenységgel összefüggő munkavégzéshez kapcsolódó utazások. A rokonlátogatások, a magyarországi nyaraló karbantartási munkálatainak elvégzése, az ingatlan adás-vétel céljából történő beutazás, a külföldi munkáltató által kiadott tíz napos kényszerszabadság család körében történő eltöltése nem tartozik a méltányolható körülmények közé.

\section{Amit mindenki szeretett volna elkerülni: a karantén}

Az egészségügyről szóló 1997. évi CLIV. törvény (Eütv.) 6. cím alatt foglalkozik a járványüggyel. A járványügyi tevékenység fő céljának a fertőző megbetegedések, a járványok megelőzését és leküzdését tekinti, amelynek megvalósítása érdekében az egészségügyi államigazgatási szerv az egyén személyes szabadsághoz való jogainak gyakorlását korlátozhatja. $^{38}$

Az Eütv. 65. § (1) bekezdés: „Azt, aki meghatározott fertőző betegségben szenvedő személlyel érintkezett és feltehetően maga is a betegség lappangási szakában van, az egészségügyi államigazgatási szerv a miniszter rendeletében meghatározott fertőző betegségek esetén járványügyi megfigyelés vagy járványügyi zárlat alá helyezi."

Az Eütv. alkalmazásában fertőző betegen a fertőző betegségre gyanús személyt is érteni kell. Fertőző betegségre gyanús személy az, aki a miniszter rendeletében meghatározott fertőző betegségben szenvedő személlyel, annak használati eszközével, váladékával érintkezett, illetve a fertőzés terjedési módjából adódóan feltételezhető, hogy a fertőző betegség kórokozója a szervezetébe került. ${ }^{39}$

\footnotetext{
37 Közlemény az államhatár személyforgalomban történő átlépése során irányadó szabályok alóli felmentés tárgyában a rendészeti országos rendőrfőkapitány-helyettes által meghozható méltányossági döntés iránt benyújtható elektronikus kérelem formai és tartalmi szabályairól.

38 1997. évi CLIV. törvény az egészségügyről 56. § (1)-(2) bek.

39 Eütv. 56. § (4) bek.
} 
A miniszteri rendeletben meghatározott fertőző betegséggel azonos tekintet alá esik az Egészségügyi Világszervezet 2009. évi XCI. törvénnyel kihirdetett Nemzetközi Egészségügyi Rendszabályai (NER) rendelkezéseire tekintettel nemzetközi horderejü közegészségügyi-járványügyi szükséghelyzet előidézésére képes, korábban ismeretlen vagy szokatlanul súlyos formában, illetve a megszokottnál lényegesen nagyobb gyakorisággal, járványosan előforduló betegség vagy állapot is.

A NER rendelkezéseire tekintettel a WHO által kihirdetett nemzetközi horderejű közegészségügyi-járványügyi szükséghelyzet előidézésére képes új koronavírus által okozott betegség egy tekintet alá esik a miniszter rendelete szerint járványügyi zárlatot szükségessé tevő betegségekkel.

A fertőző betegségek és a járványok megelőzése érdekében szükséges járványügyi intézkedésekről szóló 18/1998. (VI. 3.) NM rendelet szerint: „29. § (1) Amennyiben az 1. számú melléklet az adott fertőző betegség tekintetében kötelezővé teszi, a fertőző beteggel érintkezett személyeket járványügyi megfigyelés alá kell helyezni."

$\mathrm{Az}$ olaszországi síelésből hazatérő magyar állampolgárok tehát megfigyelés alá kerültek, mert lehet, hogy érintkeztek olyan személlyel, aki fertőző betegségre gyanús. Nem tudjuk, hogy beteggel érintkeztek-e, nem tudjuk, hogy gyanús személlyel érintkeztek-e, de a vírus gócpontjából, európai terjedésének irányából ez alaposan feltételezhető (?).

Az Eütv. alapján a fertőző betegeket el kell különíteni, ha állapotuk megengedi, akár otthonukban is sor kerülhet erre. Azt, aki meghatározott fertőző betegségben szenvedő személlyel érintkezett, és lehet, hogy megfertőződött az egészségügyi államigazgatási szerv a járványügyi megfigyelés vagy járványügyi zárlat alá helyezi. A megfigyelés során együtt kell működni az egészségügyi dolgozókkal, vizsgálatokon kell részt venni, mintát kell adni, gyógykezelésen kell részt venni, stb. A zárlat szigorított, speciális követelményeken alapuló megfigyelés, illetve elkülönítés, amelyet e célra kijelölt helyen kell foganatosítani, és amely hely nem hagyható el. ${ }^{40}$

\subsection{A hatósági házi karantén}

Az Eütv. a 67/A. §-sal kiegészülve a már meglévő jogintézményeket az aktuális helyzetnek megfelelőre alakította át, létrejött tehát a hatósági házi karantén. ${ }^{41} \mathrm{~A}$ járványügyi hatóság a fertőzés vagy megbetegedés esetén túl - igazodva a jogszabályi vélelemhez, amely szerint adott országban olyan magas a fertőzöttek száma, hogy a hazánkba beutazó személy nagy valószínűséggel fertőződhetett - a meghatározott országokból beutazókat kötelezheti hatósági házi karanténban tartózkodásra. Az elrendelés nem kötelező, hisz a beutazó igazolhatja, hogy jelen esetben a Covid-19-fertőzésből gyógyult, vagy hogy a beutazását megelőzően közvetlenül már két hétig hatósági karanténban volt. Ha a beutazó

\footnotetext{
Eütv. 67. .

41 2020. évi LVIII. törvény a veszélyhelyzet megszủnésével összefüggő átmeneti szabályokról és a járványügyi készültségről 309. §.
} 
nem kíván karanténba vonulni, és a mentesítő okok egyike sem áll fent, akkor meg kell tagadni a beléptetését az ország területére.

A döntés közlésére vonatkozóan a kialakult gyakorlatot emelték jogszabályba, mivel a hatóság a házi karanténra vonatkozó döntést szóbeli, rövid úton való közlését követően írásban is megküldi az ügyfélnek. A határátkelőhelyen a kötelező egészségügyi szűrést követően a beléptetést végző rendőr tájékoztatást ad a járványügyi megfigyelés ideiglenes intézkedésként történő elrendeléséről, majd a kitöltött formanyomtatvány alapján indult eljárásban a járási kormányhivatal népegészségügyi jogkörében eljárva fogja meghozni a döntését és postázni a határozatát az ügyfélnek. ${ }^{42} \mathrm{~A}$ járási hivatal ügyintézői az általános közigazgatási rendtartásról szóló 2016. évi CL. törvény (Ákr.) alapján tisztázzák a tényállást, hozzák meg döntésüket. A bizonyítás ebben az esetben az ügyfelet terheli, a beutazónak kell hitelt érdemlően igazolnia a jogszabályban előírtak megvalósulását (mentesítő okok meglétét). Az ellenőrzést végző rendőrnek az államhatáron nincs lehetősége bizonyítási eljárást lefolytatni, tekintettel arra, hogy nincs megállapodás arra vonatkozóan az országok között, hogy milyen okiratok fogadhatók el igazolásként (például meghívólevél, szerződés, különféle vírusteszteredmények), ezért a rendőr elrendeli a hatósági házi karantént, amely döntést a járási hivatal - megfelelő információk birtokában - a későbbiek során módosíthat.

A fentiek miatt nagyon lényeges az Eütv. 67/A. § (4) bekezdése, mert a törvénymódosítás révén a beléptetés kapcsán méltányossági jogkört gyakorló rendészeti országos rendőrfőkapitány-helyettes és a karantént határozattal elrendelő járási hivatalok között negatív hatásköri összeütközés alakult ki az államhatárt átlépő és 14 napos karanténba kerülő ügyfelek kérelmeinek elbírálása tekintetében. Az Eütv. fent említett rendelkezése szerint: „A hatósági házi karantént előíró rendelkezések alól - amennyiben a járványügyi védekezés hatósági házi karantén alkalmazása nélkül is biztosítható - különös méltánylást érdemlő esetben - egészségügyi válsághelyzetben a kormány rendeletében meghatározott esetek kivételével - a hatósági házi karantént elrendelő határozat kiadására illetékes járványügyi hatóság felmentést adhat, illetve egyedi magatartási szabályt állapíthat meg."

\subsection{A karantén ellenörzése}

Minden intézkedés annyit ér, amennyit betartanak belőle. Fontos tehát, hogy az államhatárt átlépő, karanténba kerülő személy tényleg a legrövidebb úton jusson el a számára kijelölt helyre, és az azt követő 14 napban tartózkodjon is ott.

$\mathrm{Az}$ államhatárt átlépő személyt a rendőr tájékoztatja a 14 napos karanténról majd a két példányban kitöltött „a járványügyi megfigyelés ideiglenes intézkedésként történő

42 Hatáskör: 1991. évi XI. törvény az egészségügyi hatósági és igazgatási tevékenységről 11. § (5) bekezdés, illetékesség: 385/2016. (XII. 2.) Korm. rendelet a fóvárosi és megyei kormányhivatal, valamint a járási (fővárosi kerületi) hivatal népegészségügyi feladatai ellátásáról, továbbá az egészségügyi államigazgatási szerv kijelöléséről 5. §, 2. számú melléklet. 
elrendeléséről” szóló tájékoztató egyik példányát és a kihelyezendő figyelmeztető feliratokat átadja részére. Az ügyfél által aláirt másik példány alapján a határátkelőhely szerint illetékes rendőrkapitányság elrendeli az ügyfél körözését, majd a lakhely/tartózkodási hely szerint illetékes rendőrkapitányságnak mint körözésirányítónak megküldi, amely így értesül arról, hogy az illetékességi területén karantént rendeltek el, és ellenőrzési kötelezettsége keletkezett. Az ellenőrzéseket az együttmúködő szervek bevonásával a rendőrség végzi, kerülve az ellenőrzöttel a közvetlen kontaktust (például személyazonosítás ablakon keresztül), lehetőség szerint - a szolgálati feladatok figyelembevételével - naponta. A körözési rendszerben történő rögzítés a közterületi ellenőrzések során biztosítja az intézkedő rendőr számára a karantén szabályait megsértő személy felfedését. Az intézkedés során - ha az intézkedés alá vont egészségügyi állapota nem indokolja a mentő helyszínre hívását - a körözöttet a karanténként kijelölt ingatlanba kell irányítani, majd ellenőrizni kell az ottlétét.

Az ellenőrzés komoly feladatot jelentett a rendőrség számára. Május hónapban az aktuális érvényben lévő hatósági házi karanténok száma tízezer felett, a végrehajtott ellenőrzések száma félmillió körül mozgott. Az Operatív Törzs 2020. május 11-én tartott tájékoztatója szerint az állampolgárok döntő többsége betartja a hatósági házi karantén szabályait, és a lakosság szabálykövető magatartása hozzájárult a járvánnyal szembeni sikeres védekezéshez, a hatósági házi karanténban lévők mindössze 0,41\%-a szegte meg a szabályokat. ${ }^{43}$

\subsection{Elektronikus hatósági házi karantén ellenörzése}

2020. május 7-én lépett hatályba az élet- és vagyonbiztonságot veszélyeztető tömeges megbetegedést okozó humán járvány vonatkozásában elrendelt hatósági házi karantén elektronikus ellenőrzéséről szóló 181/2020. (V. 4.) Korm. rendelet (181/2020. Korm. rendelet). A rendelet alapján a járványügyi hatóság elrendeli a hatósági házi karantén szabályai betartásának az érintett személy mozgását nyomon követő, valamint az arcképmásának és általa megadott egészségügyi adatainak továbbítására alkalmas elektronikus szoftver alkalmazásával történő ellenőrzését, ha a technikai feltételek adottak és az érintett önként vállalja a Házi Karantén Rendszer (HKR) alkalmazását. A HKR egy okostelefon-alkalmazás, amely az arcfelismerésen és a helyzetmeghatározáson alapul.

A rendőrség a szoftver útján megadott mozgási adatokat elektronikus úton összeveti a hatósági házi karanténra kijelölt hely adataival. A rendszer bejelentkezési kéréseket küld az érintett személynek e-mailben vagy SMS-ben, amelyre 15 percen belül reagálni kell, el kell indítani az alkalmazást, szelfit kell küldeni a rendőrség részére a személyazonosság és a tartózkodási hely megállapítása érdekében. A személyes ellenőrzésre akkor kerülhet sor, ha a szoftver által biztosított ellenőrzés kijátszásának gyanúja merül fel, vagy ha az érintett személy a szoftver használatát elmulasztja. A személyes ellenőrzést

43 Operatív törzs: tovább nött az önkéntes elektronikus ellenőrzést vállaló házi karanténban lévôk száma. 2020. 
megelőzően ismételt távellenőrzési felhívás hangzik el, illetve a rendszerkezelő telefonon is megpróbálja a karanténban lévővel felvenni a kapcsolatot, kiküszöbölve az önhibán kívüli (például hálózati problémák) vagy elfogadható okok miatt elmulasztott bejelentkezéseket követő intézkedéseket. Az ellenőrzés nem járhat az érintett személy magánéletének szükségtelen zavarásával, ezért 22.00 és 6.00 óra között az érintett személy pihenése indokolatlanul nem zavarható meg.

A HKR igazolta létjogosultságát, a karanténban lévők számára könnyebben elviselhetôvé teszi, a hatóság számára egyszerüsíti a szabályok betartásának ellenőrzését a koronavírus-járvány alatt. ${ }^{44}$

\section{Záró gondolatok}

A Johns Hopkins Egyetem által 2020. július 14-én közzétett adatok alapján a világban az új koronavírustól 13249575 ember fertőződött meg és 575844 ember halt meg. Magyarországon 4258 megbetegedettből 595 halálozott el, és jelenleg is 557 fertőzött van nyilvántartva. ${ }^{45}$

A számok magukért beszélnek. A járvány az egész világot sújtotta, az eddig csak filmekben látott események valósággá váltak. Az új koronavírus, a SARS-CoV-2, néhány hónap alatt a föld szinte minden pontját elérte.

Az országok a nemzetközi szervezetek ajánlásait figyelembe véve, egymással szorosan együttmúködve megkezdték a védekezést. Magyarországon is felállították az operatív törzset, bevezették a veszélyhelyzetet, a törvényi felhatalmazást követően a jogszabályi hátteret a kormányrendeletek biztosították.

A védekezésben a határellenőrzések ideiglenes visszaállítása, a védelmi intézkedések betartásának ellenőrzése, a jogsértő magatartások szankcionálása, a kórházparancsnoki rendszer múködtetése révén a rendőrség is kiemelt szerepet játszott, hozzájárulva ahhoz, hogy Magyarország eredményesen tudjon védekezni a koronavírus ellen.

\section{IRODALOMJEGYZÉK}

A 2020. évben azonositott új koronavírus (SARS-CoV-2) okozta fertőzések (COVID-19) megelōzésének és terápiájának kézikönyve. Emberi Erőforrások Minisztériuma, 2020.

Patyi András: A közigazgatási müködés jogi alapjai. A magyar közigazgatás és közigazgatási jog általános tanai II. kötet. Budapest, Dialóg Campus, 2017.

Szalai András: A közigazgatási jog alapjai. Budapest, Dialóg Campus, 2018.

Szilvásy György Péter: A rendészet jogi szabályozása Magyarországon. In Szigeti Péter - Szilvásy György Péter: Rendészet és emberi jogok. Budapest, Rejtjel, 2015. 66-68.

44 Jól működik a hatósági házi karantén elektronikus ellenốrzése. 2020.

45 Legfrissebb információ az új koronavírus-járványról (COVID-19). 


\section{Jogi források}

Magyarország Alaptörvénye

1997. évi CLIV. törvény az egészségügyről

2012. évi II. törvény a szabálysértésekről, a szabálysértési eljárásról és a szabálysértési nyilvántartási rendszerről

2020. évi XII. törvény a koronavírus elleni védekezésről

2020. évi LVII. törvény a veszélyhelyzet megszüntetéséről

2020. évi LVIII. törvény a veszélyhelyzet megszűnésével összefüggő átmeneti szabályokról és a járványügyi készültségről

18/1998. (VI. 3.) NM rendelet a fertőző betegségek és a járványok megelőzése érdekében szükséges járványügyi intézkedésekről

40/2020. (III. 11.) Korm. rendelet a veszélyhelyzet kihirdetéséről

41/2020. (III. 11.) Korm. rendelet az élet- és vagyonbiztonságot veszélyeztető tömeges megbetegedést okozó humánjárvány megelőzése, illetve következményeinek elhárítása, a magyar állampolgárok egészségének és életének megóvása érdekében elrendelt veszélyhelyzet során teendő intézkedésekről

46/2020. (III. 16.) Korm. rendelet az élet- és vagyonbiztonságot veszélyeztető tömeges megbetegedést okozó humánjárvány megelőzése, illetve következményeinek elhárítása, a magyar állampolgárok egészségének és életének megóvása érdekében elrendelt veszélyhelyzet során teendő intézkedésekről

71/2020. (III. 27.) Korm. rendelet a kijárási korlátozásról

81/2020. (IV. 1.) Korm. rendelet az egészség és élet megóvása, valamint a nemzetgazdaság helyreállítása érdekében elrendelt veszélyhelyzettel kapcsolatos rendkívüli intézkedésekről

85/2020. (IV. 5.) Korm. rendelet a veszélyhelyzet során alkalmazandó egyes belügyi és közigazgatási tárgyú szabályokról

119/2020. (IV. 16.) Korm. rendelet a veszélyhelyzet során az érettségi vizsgák 2020. május-júniusi vizsgaidőszakban történő megszervezéséről

168/2020. (IV. 30.) Korm. rendelet a védelmi intézkedésekről

174/2020. (IV. 30.) Korm. rendelet az egészség és élet megóvása, valamint a nemzetgazdaság helyreállítása érdekében elrendelt veszélyhelyzettel kapcsolatos rendkívüli intézkedésekről szóló 81/2020. (IV. 1.) Korm. rendelet módosításáról

181/2020. (V. 4.) Korm. rendelet az élet- és vagyonbiztonságot veszélyeztető tömeges megbetegedést okozó humánjárvány vonatkozásában elrendelt hatósági házi karantén elektronikus ellenőrzéséről

185/2020. (V. 6.) Korm. rendelet az egészség és élet megóvása, valamint a nemzetgazdaság helyreállítása érdekében elrendelt veszélyhelyzettel kapcsolatos rendkívüli intézkedésekről

194/2020. (V. 11.) Korm. rendelet a különös méltányossági jog gyakorlásának rendjéről

1012/2020. (I. 31.) Korm. határozat a Koronavírus-járvány Elleni Védekezésért Felelős Operatív Törzs felállításáról

T/10747. számú törvényjavaslat indokolással - a veszélyhelyzet megszüntetéséről

Közlemény az államhatár személyforgalomban történő átlépése során irányadó szabályok alóli felmentés tárgyában a rendészeti országos rendőrfőkapitány-helyettes által meghozható méltányossági döntés iránt benyújtható elektronikus kérelem formai és tartalmi szabályairól

A Bizottság (2020/C 96 I/01) közleménye a zöld sávoknak az egészség védelmét, valamint az áruk és az alapvető szolgáltatások rendelkezésre állását biztosító határigazgatási intézkedésekre vonatkozó iránymutatások szerinti végrehajtásáról 


\section{Internetes források}

Coronavirus: Five Britons in French ski chalet catch virus. 2020. Elérhető: www.bbc.com/news/uk51425702 (A letöltés dátuma: 2020. 06. 18.)

Pandémia. Wikipédia, a szabad enciklopédia. Elérhető: https://hu.wikipedia.org/wiki/ Pand\%C3\%A9mia (A letöltés dátuma: 2020. 06. 18.)

COVID-19-pandémia. Wikipédia, a szabad enciklopédia. Elérhető: https://hu.wikipedia.org/wiki/COVID\%E2\%80\%9319-pand\%C3\%A9mia (A letöltés dátuma: 2020. 06. 18.)

Pulai László: A BM válaszolt: lehet müszakiztatni, de nem muszáj. 2020. Elérhető: https://hegylakok. hu/2020/03/muszaki-vizsga-veszelyhelyzetben-a-bm-valaszol/ (A letöltés dátuma: 2020. 06. 24.)

Ügyféltájékoztató. Rendőrség. Elérhető: www.police.hu/hu/hirek-es-informaciok/legfrissebb-hireink/ igazgatasrendeszet/ugyfeltajekoztato-0 (A letöltés dátuma: 2020. 06. 24.)

2010-2020. évek közötti idöszak statisztikai kimutatása. Igazgatásrendészeti szakterület. Országos Rendőr-főkapitányság Rendészeti Főigazgatóság. Elérhető: www.police.hu/sites/default/files/ Igazgatasrendeszet\%20SK\%202020.\%2005.pdf (A letöltés dátuma: 2020. 06. 24.)

Operativ törzs: tovább noott az önkéntes elektronikus ellenőrzést vállaló házi karanténban lévők száma. 2020. Elérhető: https://koronavirus.gov.hu/cikkek/operativ-torzs-tovabb-nott-az-onkenteselektronikus-ellenorzest-vallalo-hazi-karantenban (A letöltés dátuma: 2020. 07. 06.)

Jól müködik a hatósági házi karantén elektronikus ellenörzése. 2020. Elérhető: https://koronavirus.gov. hu/cikkek/jol-mukodik-hatosagi-hazi-karanten-elektronikus-ellenorzese (A letöltés dátuma: 2020. 07. 06.)

Legfrissebb információ az új koronavírus-járványról (COVID-19). Elérhető: www.trt.net.tr/magyar/ covid19 (A letöltés dátuma: 2020. 07. 14.)

\section{ABSTRACT}

\section{The Police against the Coronavirus}

Tamás SKORKA

The pandemic caused by the coronavirus also reached Hungary, and the measures introduced to deal with the situation had serious consequences for the whole country. My study examines the tasks assigned to the police, in particular the measures introduced at the state border. Closely related to the study is my other paper, which details the responsibilities of the administrative police service branch within the police by describing the new offence facts introduced in connection with the emergency.

Keywords: coronavirus, emergency, border control, transit, fair entry, quarantine 